\title{
Manajemen Kurikulum
}

\section{Pesantren Salaf Darul Falah "Amtsilati" Jepara}

\author{
Mufassirul Alam ${ }^{1}$, Fikri Maulana ${ }^{2}$ \\ ${ }^{12}$ Institut PTIQ Jakarta, Indonesia \\ ${ }^{1}$ mufassirulalam@ptiq.ac.id \\ 2fikrimaulana@ptiq.ac.id
}

\begin{abstract}
Abstrak
Penelitian ini memiliki tujuan mendeskripsikan manajemen kurikulum di Pondok Pesantren Darul Falah "Amtsilati" Jepara yang berkenaan dengan perencanaan kurikulum, pengorganisasian kurikulum, implementasi kurikulum, dan evaluasi kurikulum. Adapun latar belakang penelitian ini yakni karena pesantren salaf ini memiliki manajemen kurikulum yang khas dibanding pesantren salaf yang lain. Penelitian ini menggunkana metode penelitian kualitatif deskriptif. Teknik pengumpulan data pada penelitian ini melalui wawancara, observasi, dan studi dokumentasi. Adapun analisis data melalui dua tahapan. Tahap pertama, analisis studi pendahuluan sebelum di lapangan. Tahap kedua, analisis data di lapangan dengan reduksi data, penyajian data, dan penarikan kesimpulan. Hasil penelitian menunjukkan perencanaan kurikulum dilakukan dengan pembatasan kurikulum dan perumusan silabus. Pengorganisasian kurikulum dilakukan dengan penetapan struktur kurikulum dan pembagian tugas guru atau ustaz. Implementasi kurikulum dilakukan dengan proses pengalaman pengajaran dan penilaian serta laporan hasil belajar. Evaluasi kurikulum dilakukan dengan mengevaluasi mata pelajaran dan mengevaluasi waktu penyelesaian pengajaran.
\end{abstract}

Kata Kunci: Manajemen Kurikulum, Pesantren Salaf, Amtsilati

\begin{abstract}
This study aims to describe the curriculum at the Darul Falah Islamic Boarding School "Amtsilati" Jepara related to curriculum planning, curriculum organization, curriculum implementation, and curriculum evaluation. This research is motivated because this salaf pesantren has a unique curriculum compared to other salaf pesantren. This research uses descriptive qualitative research method. Data collection techniques in this study were through interviews, observation, and documentation studies. Data analysis went through two stages. The first stage, analysis of the preliminary study before going to the field. The second stage, data analysis in the field with data reduction, data presentation, and drawing conclusions. The results showed that the curriculum was implemented with the curriculum and syllabus formulation. The organization of the curriculum is done by determining the curriculum and the division of tasks for teachers or ustaz. The implementation of the curriculum is carried out through a learning process and assessment as well as a report on learning outcomes. Evaluation is done by studying the subjects and the time of the learning implementation.
\end{abstract}


Keywords: Curriculum Management, Salaf Islamic Boarding School, Amtsilati

\section{Pendahuluan}

Islam adalah agama yang mengarahkan umatnya dengan petunjuk-petunjuk yang ada dalam al-Quran, baik yang bersifat hudan linnas maupun yang hudan lil muttaqin. ${ }^{1}$ Dalam agama Islam ada lembaga pembelajaran yang bernama pesantren. Setelah itu pesantren ini dibagi jadi pesantren salaf serta pesantren modern.

Pesantren salaf masih jadi opsi utama warga dalam belajar serta mendalami ilmu agama. Perihal ini disebabkan, kurikulum pesantren salaf dirancang buat penuhi tuntutan tersebut dengan mengkaji kitab kuning karya ulama salaf selaku sumber ilmu agama Islam sehabis alQur'an serta Hadits. Sebagaimana hasil riset Rustam Ibrahim yang menarangkan kalau Kurikulum pesantren salaf sangat membolehkan santri buat mendalami ilmu agama lewat kitab kuning yang jadi ilmunya ulama salaf. Kurikulum tersebut jadi tujuan santri buat mendalami ilmu agama di pondok pesantren. ${ }^{2}$ Dengan demikian, hingga kurikulum pesantren salaf wajib dikelola dengan baik supaya tujuan luhur tersebut bisa tercapai.

Bila memandang sejarah, pondok pesantren ialah lembaga pembelajaran terlama yang terdapat di Indonesia, kedatangan pondok pesantren bisa ditinjau bertepatan dengan perkembangan Islam di Indonesia semenjak abad ke- 18 serta ke- 19 masehi hingga saat ini masih eksis serta tumbuh. ${ }^{3}$

Berikutnya, pondok pesantren tumbuh dengan sangat pesat. Bila memandang informasi dari Departemen Agama, pada tahun 1977 pesantren cuma berjumlah 4.195 tempat serta santri 677.394 orang. Setelah itu pada tahun 1985 kenaikan signifikan terjalin, pesantren berjumlah jadi 6.239 tempat serta santri 1.084 .801 orang. $^{4}$

Ada pula dari informasi statistik Ditjen Kelembagaan Islam, Kementerian Agama Republik Indonesia yang dilansir oleh Republika (republika. co. id) pada tahun 2001 pesantren terdapat 11.312 dengan 2.737.805 santri. Berikutnya, pada tahun 2005 jumlah pesantren

\footnotetext{
${ }^{1}$ Fikri Maulana, "Pendidikan Kewirausahaan Dalam Islam," IQ (Ilmu Al-Qur'an): Jurnal Pendidikan Islam 2, no. 01 (January 1, 2019): 30-44, https://doi.org/10.37542/IQ.V2I01.23.

${ }^{2}$ Studi Multisitus et al., "EKSISTENSI PESANTREN SALAF DI TENGAH ARUS PENDIDIKAN MODERN The Existence of Salaf Islamic Boarding School amid the Flow of Modern Education (A Multi-Site Study at Pesantren Salafy in Central Java)," no. 1 (2014): 253-63.

3 Abd. Muin M dkk, Pesantren dan Pengembangan Ekonomi Umat, (Jakarta: CV. Prasasti, 2007), 16.

${ }^{4}$ www.kemenag.go.id. (Diakses 25 Desember 2017). 
kembali bertambah jadi 14.798 pesantren dengan santri berjumlah 3.464 .334 orang. $^{5}$

Sedangkan itu, bersumber pada Bagian Informasi, Sistem Data, serta Ikatan Warga Sekretariat Direktorat Jenderal Pembelajaran Islam Departemen Agama, pada tahun 2016 ada 28.194 pesantren yang tersebar baik di daerah kota ataupun pedesaan dengan 4.290.626 santri. ${ }^{6}$. Untuk lebih jelasnya dapat dilihat pada grafik berikut ini:

\section{Grafik 1. Data Perkembangan Pondok Pesantren di Indonesia}

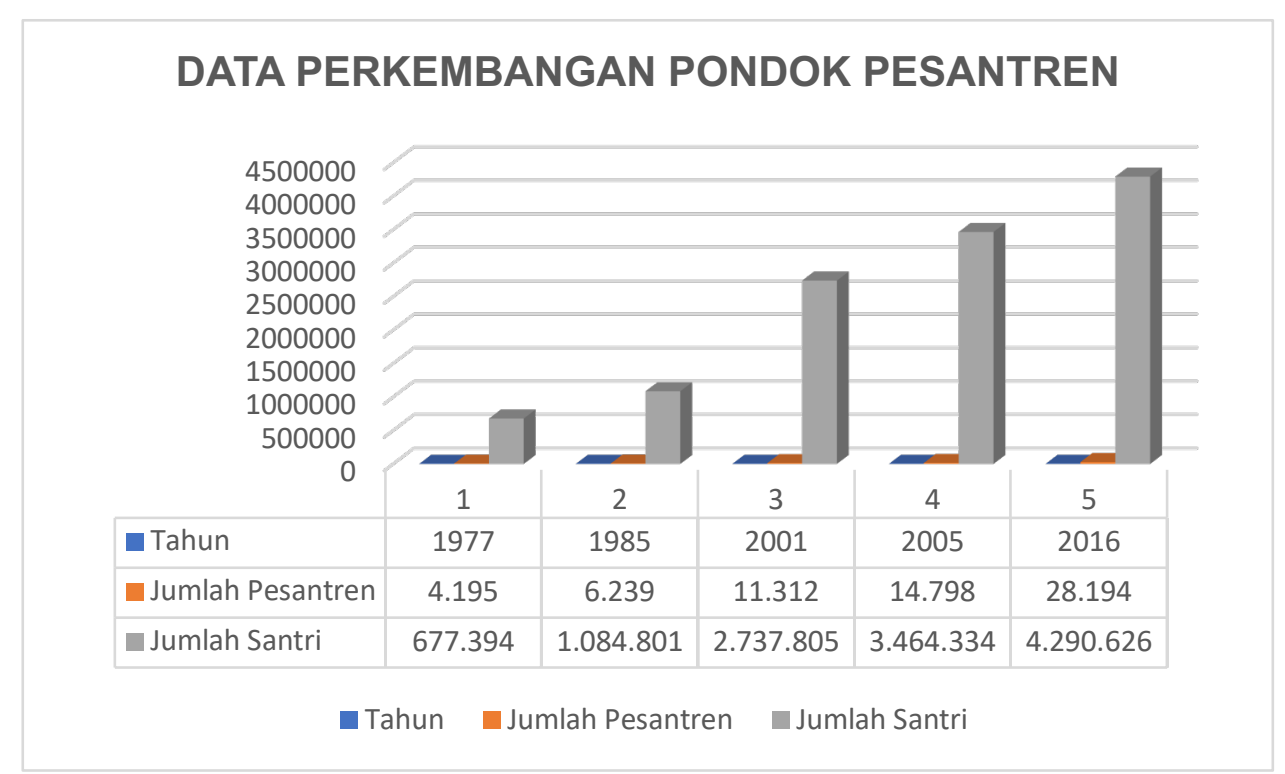

Pondok pesantren mengarahkan ilmu- ilmu yang berkaitan dengan Agama Islam memakai kitab berbahasa Arab cocok dengan tingkatannya. Pengajaran dengan metode sorogan, wetonan serta bandongan masih senantiasa dipertahankan, namun telah banyak pula yang sudah memakai klasikal dalam wujud Madrasah.

Ada pula komponen berarti dalam penyelenggaraan pembelajaran merupakan gimana kurikulum yang diselenggarakan dalam pondok pesantren tersebut. Permasalahan kurikulum jadi pembicaraan yang menarik atensi, paling utama dalam dunia pondok pesantren. Dari kurikulum tersebut jadi dimensi atas mutu sesuatu lembaga pembelajaran tercantum di dalamnya merupakan pondok pesantren. Kurikulum ialah wajah dari suatu lembaga pembelajaran, sehingga dapat dilihat selaku cerminan dari lulusannya nanti dan proses Pengajarannya.

Dari sekian banyak pondok pesantren yang terdapat, pesantren salaf ialah pondok pesantren dengan jumlah yang paling banyak, ialah dekat 13.446 pondok pesantren. ${ }^{7}$ Pesantren

${ }^{5}$ www.republika.co.id. (Diakses 12 September 2021).

${ }^{6}$ www.pendis.kemenag.go.id. (Diakses 12 September 2021).

7 http://pendis.kemenag.go.id/file/dokumen/bukusaku1102.pdf. (Diakses 12 September 2021). 
salaf ialah pondok pesantren yang senantiasa mempertahankan sistem pembelajaran khas pondok pesantren dengan Pengajaran kitab kuning ataupun kitab gundul yang dimulai dengan Pengajaran nahwu sharaf selaku modul pokok yang dikelola secara mandiri baik kurikulumnya ataupun proses belajar- mengajarnya.

Di antara pesantren salaf yang jumlahnya lumayan banyak tersebut, ada pesantren salaf yang menarik atensi warga pada tahun 2000-an. Pesantren salaf ini muncul dengan suatu yang baru. Dimana umumnya seseorang santri baru dapat memahami ilmu nahwu sharaf sehabis mondok 3 hingga 6 tahun. Karena, tidak hanya belajar kaidah nahwu sharaf yang diajarkan secara terpisah, para santri pula diharuskan mengahafal ribuan bait- bait nazham (syair) kitabkitab pegangannya. Mulai dari yang sangat bawah semacam Al- Jurumiyah, yang menengah semacam Imrithi, hingga yang tingkatan lanjut, Alfiyah Ibnu Malik. Belum lagi ratusan bait syair ilmu sharaf dalam bermacam kitab pagangannya, semacam Qowaidul Maqsud, serta lainlain.

Pesantren salaf yang bawa harapan tersebut merupakan Pondok Pesantren Darul Falah "Amtsilati" Jepara yang populer dengan tata cara andalannya bernama "Tata cara Amtsilati", pimpinan Taufiqul Hakim sekalian penemu dari tata cara Amtsilati tersebut. Hingga tidak heran bila warga luas kerap menyebutnya dengan istilah "Pondok Amtsilati".

Tata cara Amtsilati merupakan tata cara dalam belajar ilmu gramatika bahasa Arab ataupun bahasa yang lain merupakan ilmu nahwu sharaf yang ialah ilmu harus dalam belajar kitab Islam klasik karya para ulama terdahulu yang jadi menu pelajaran tiap hari di pesantren salaf.

Penanda yang menampilkan keberhasilan manajemen kurikulum yang diterapkan pada proses Pengajaran di Pondok Pesantren Darul Falah “Amtsilati” Jepara dengan umur pondok pesantren yang masih sangat muda dibanding dengan pesantren salaf yang yang lain yang berumur puluhan apalagi ratusan tahun, sudah sanggup menarik atensi warga tidak cuma di dalam negara, tetapi pula warga luar negara semacam orang Malaysia yang terencana belajar (mondok) di situ serta suatu lembaga pembelajaran yang terdapat di Singapore tertarik buat mengadopsi sistem kurikulum Pondok Pesantren Darul Falah “Amtsilati” Jepara buat diterapkan di lembaga pembelajaran yang mereka kelola. Cocok dengan yang diungkapkan oleh Najib Habibi, sebagai Sekretaris Pondok Pesantren Darul Falah “Amtsilati” Jepara.

Penanda lain yang jadi alibi diseleksi Pondok Pesantren Darul Falah “Amtsilati” Jepara selaku energi tarik kalau menawarkan kurikulum berbasis kompetisi serta kompetensi 202 | Ilmu Al-Qur'an (IQ) Jurnal Pendidikan Islam | Volume 4 No. 022021 
(kurikulum Amtsilati) dengan memakai tata cara Amtsilati yang memudahkan serta memesatkan santri memahami ilmu nahwu sharaf. Manajemen Kurikulum di Pondok Pesantren Darul Falah“ Amtsilati” Jepara dirancang dalam waktu 6 bulan santri sanggup membaca kitab kuning/ kitab gundul. ${ }^{8}$ Tidak hanya itu, modul kurikulum yang diajarkan pula lumayan komprehensif, mulai dari Fiqih Thoharoh, Ubudiyah, Muamalah, Munakahah, Jinayah, hingga kelas Tafsir.

Dengan iktikad buat memperoleh informasi yang mengatakan serta menarangkan kasus riset, hingga riset ini memakai pendekatan kualitatif ialah tata cara riset yang berlandaskan pada filsafat post-positivisme, digunakan buat mempelajari pada keadaan obyek yang alamiah (selaku lawannya merupakan eksperimen). ${ }^{9}$

Denzim serta Lincoln dalam Moleong, melaporkan kalau riset kualitatif merupakan riset yang memakai latar ilmiah, dengan iktikad menafsirkan fenomena yang terjalin serta dicoba dengan jalur mengaitkan bermacam tata cara alamiah. ${ }^{10}$

Ada pula jenis riset ini merupakan deskriptif, ialah riset yang berupaya menggambarkan serta menginterpretasikan fenomena yang lagi terjalin di lapangan. ${ }^{11}$ Riset ini memakai pendekatan kualitatif dengan rancangan/ desain riset permasalahan.

Periset memandang watak dari permasalahan yang diteliti bisa tumbuh secara alamiah cocok dengan keadaan serta suasana di lapangan, dengan tujuan buat membagikan cerminan yang jelas serta akurat tentang objek serta fenomena yang lagi diteliti ialah manajemen kurikulum Pondok Pesantren Darul Falah “Amtsilati” Jepara.

Riset deskriptif kualitatif menyajikan secara langsung hakikat ikatan antara periset serta responden yang bukan berbentuk informasi angka, melainkan perkata serta sikap orang. Riset ini tidak ditunjukan buat meyakinkan hipotesis namun menekankan kepada pengumpulan informasi faktual buat mendeskripsikan peristiwa sebetulnya di lapangan. Dalam riset kualitatif, kedatangan periset sedapat bisa jadi tidak mengganti atmosfer yang terdapat, dengan bermacam metode pengumpulan informasi secara normal oleh periset sebagaimana terdapatnya.

Ada pula prosedur dalam riset ini didahului dengan riset pendahuluan (grandtour obsevation) yang dicoba guna mendapatkan cerminan tentang kasus yang hendak diteliti,

\footnotetext{
${ }^{8}$ Majalah Kisah Islami (alKisah) No.08/7-20 April 2008, 66.

${ }^{9}$ Sugiyono, Metode Penelitian Kuantitatif, Kualitatif dan $R \&$ D, (Bandung: Alfabeta, 2013), 9.

${ }^{10}$ Lexy J. Moleong, Metodologi Penelitian Kualitatif, (Bandung: Remaja Rosdakarya, 2010), 5.

${ }^{11}$ Suharsimi Arikunto, Prosedur Penelitian, (Jakarta: Rieneka Cipta, 2000), 12.
} 
tepatnya yang terdapat di Pondok Pesantren Darul Falah “Amtsilati” Jepara. Tidak hanya itu, pula dicoba riset literature guna mencari teori- teori yang berkenaan dengan permasalahan yang diteliti.

Berikutnya, pada sesi riset di lapangan, periset mengumpulkan segala informasi serta penemuan yang diperoleh buat dicoba pengolahan informasi. Pada sesi pengolahan serta analisis informasi, periset melaksanakan reduksi informasi serta penyajian informasi dalam wujud tabel, foto, serta narasi. Sehabis pengolahan informasi berakhir, dicoba proses pengecekan keabsahan informasi dengan metode triangulasi, serta setelah itu sehabis tidak terdapat lagi informasi yang butuh ditilik ataupun dilengkapi, barulah periset melaksanakan penarikan kesimpulan.

\section{Pembahasan}

Ulasan Manajemen Kurikulum Pesantren salaf Darul Falah “Amtsilati” Jepara ini meliputi perencanaan kurikulum, pengorganisasian kurikulum, implementasi kurikulum, serta penilaian kurikulum. Secara rinci bisa dijabarkan pada ulasan berikut ini:

\section{A. Perencanaan Kurikulum}

Bagi ungkapan Curriculum planning is intented as a "how-to-do- it guide" for curriculum planners in the school system, or as a textbook for college-level courses in curriculum planning and development. ${ }^{12}$ Dengan demikian, Pondok Pesantren Darul Falah “Amtsilati” Jepara mempraktikkan perihal tersebut.

Pondok Pesantren Darul Falah "Amtsilati” Jepara, selaku suatu lembaga pembelajaran dalam melaksanakan aktivitas pembelajaran berbentuk kegiatan belajar mengajar berpedoman pada kurikulum yang sudah disusun serta disepakati antara penjaga, guru ataupun ustaz, serta pengurus pondok pesantren dalam proses perencanaan kurikulum supaya jadi perlengkapan bersama dalam menggapai tujuan pembelajaran yang diharapkan.

Perencanaan kurikulum Pondok Pesantren Darul Falah “Amtsilati” Jepara mengacu pada suatu sistem yang "berbasis kompetisi serta kompetensi". Artinya para santri dituntut buat mempunyai kompetensi ilmu nahwu sharaf selaku bekal belajar kitab

12 Weldon F. Zenger and Sharon K. Zenger, Curriculum Planning: Outcames-Based Accountability. Direction Journal Vol. 23 No. 2, 1994. http://www.directionjournal.org/23/2/curriculum-planning-outcomesbased.html. (Diakses 20 Januari 2021).

204 | Ilmu Al-Qur'an (IQ) Jurnal Pendidikan Islam | Volume 4 No. 022021 
kuning selaku karakteristik khas dari pesantren salaf. Tidak hanya itu, para santri pula dituntut buat berlomba-lomba dalam menuntaskan modul pelajarannya sedini bisa jadi. Dengan begitu santri yang giat serta tekun kilat berakhir, lulus, serta wisuda.

Sistem ini ditunjang dengan tata cara Pengajaran Amtsilati. Suatu tata cara terobosan baru dalam belajar kaidah Bahasa Arab (ilmu nahwu sharaf) selaku bekal serta kunci dalam belajar kitab kuning. Tata cara ini disusun oleh KH. Taufiqul Hakim, pendiri sekalian penjaga Pesantren Darul Falah “Amtsilati” Jepara. Tata cara inilah yang setelah itu jadi semacam ruh ataupun pondasi dari bangunan sistem pembelajaran yang digunakan di Pondok Pesantren Darul Falah “Amtsilati” Jepara. Sehingga kurikulum pondok pesantrennya dapat diucap 'Kurikulum Amtsilati', ialah kurikulum yang berbasis kompetisi serta kompetensi.

Perencanaan kurikulum di Pondok Pesantren Darul Falah “Amtsilati” Jepara menciptakan pedoman dalam melaksanakan kurikulum pondok pesantren. Pedoman kurikulum tersebut dibutuhkan selaku petunjuk teknis serta petunjuk penerapan supaya kurikulum yang dijalankan dapat terencana. Sebagaimana statment Zenger and Zenger, yang berkata perencanaan kurikulum terbuat buat jadi petunjuk kerja (kurikulum).

Prinsip bawah Pondok Pesantren Darul Falah “Amtsilati” Jepara mempraktikkan sistem berbasis kompetisi serta kompetensi dalam kurikulumnya merupakan tidak lain mengakui serta mengapresiasi santri-santri yang pintar serta giat, tetapi senantiasa membimbing santri yang pemahamannya agak lelet. Dengan demikian, terwujud persaingan yang sehat dalam belajar, santri berlomba- lomba buat kilat berakhir.

Prosedur serta langkah-langkah dalam perencanaan kurikulum di Pondok Pesantren Darul Falah “Amtsilati” Jepara, awal ialah arahan dari penjaga pondok pesantren, sebagai pimpinan paling tinggi, setelah itu penjaga membagikan mandat serta wewenang kepada pengurus pondok pesantren, sehabis itu pengurus pondok pesantren mengejawantahkannya kepada hal-hal yang lebih teknis dengan membuat petunjuk penerapan serta petunjuk teknis.

Ada pula ulasan perencanaan kurikulum di Pondok Pesantren Darul Falah “Amtsilati” Jepara dibahas antara penjaga, guru, pimpinan pondok, serta pengurus pondok pesantren bidang pembelajaran. Penjaga selaku pemberi arahan serta perintah, setelah itu dibahas di tingkatan dewan pengurus serta dewan guru pondok pesantren buat memastikan batasan- batasan modul kurikulum yang dipelajari buat tiap- tiap kelas di tiap di jenjang pembelajaran. Sehabis itu diajukan ke penjaga buat memohon persetujuan sekalian 
pengesahan, baru setelah itu dijalankan selaku sesuatu kebijakan kurikulum pondok pesantren.

Pada pendekatan yang bertabiat "administrative approach", kurikulum direncanakan oleh pihak atasan setelah itu diturunkan kepada struktur-struktur yang terdapat di bawahnya hingga kepada tenaga pendidik (guru/ ustaz). Perihal ini seirama dengan komentar Hamalik, yang berkata ada 2 pendekatan dalam melakukan perencanaan kurikulum, ialah administrative approach serta grass roots approach.

Hingga sifatnya from the top down. Dalam keadaan ini guru/ ustaz selaku garda terdepan dalam mendidik tidak dilibatkan. Mereka lebih bertabiat pasif ialah selaku penerima serta pelaksana di lapangan. Seluruh ilham, gagasan, serta inisiatif berasal dari pihak atasan.

Sedangkan itu, dalam pendekatan yang bertabiat "grass roots approach" yang berarti diawali dari dasar, pimpinan lembaga pembelajaran beserta tenaga pendidik (guru/ ustaz) bisa merancang kurikulum secara bersama- sama apalagi hingga pada pergantian kurikulum apabila ada kekurangan- kekurangan dalam kurilkulum yang berlaku.

Perencanaan kurikulum Pondok Pesantren Darul Falah “Amtsilati” Jepara tertuang dalam dokumen kurikulum pondok pesantren yang berisi panduan kurikulum buat tiap-tiap jenjang Pembelajaran, baik jenjang pembelajaran Amtsilati ataupun jenjang pembelajaran Pasca Amtsilati, tercantum struktur program kurikulum yang wajib dituntaskan pada masing- masing tingkatannnya.

Ulasan terpaut kurikulum Pondok Pesantren Darul Falah "Amtsilati” Jepara dicoba pada dini tahun ajaran baru, ialah bulan Syawal. Ulasan dicoba lewat musyawarah pengurus pondok pesantren, setelah itu disetujui oleh pimpinan pondok, sehabis itu disahkan oleh penjaga selaku pimpinan paling tinggi pondok pesantren.

Jadi, secara universal perencanaan kurikulum di Pondok Pesantren Darul Falah “Amtsilati” Jepara terdiri dari 2 tahapan. Awal, pembatasan kurikulum. Kedua, formulasi silabus.

\section{Pembatasan Kurikulum}

Pembatasan kurikulum dicoba buat memastikan beban belajar pada tiap- tiap jenjang pembelajaran dan pada tiap- tiap tingkatan kelas. Pembatasan kurikulum dicoba dengan pimpinan pondok membagi tugas tiap- tiap anggota yang terdiri dari perwakilan jenjang pembelajaran Amtsilati serta jenjang pembelajaran Pasca Amtsilati buat melaksanakan pembatasan tiap- tiap mata pelajaran. Tiap- tiap anggota melaksanakan 
pembatasan kompetensi mata pelajaran cocok tingkatannya. Hasil pembatasan kurikulum menciptakan silabus yang diverifikasi oleh pengurus bidang pembelajaran serta pimpinan pondok. Setelah itu sehabis itu, silabus disahkan oleh penjaga pondok pesantren sebagai pimpinan paling tinggi.

Pembatasan kurikulum dicoba secara kolaboratif di mana seluruh anggota yang terdiri dari kepala pembelajaran jenjang Amtsilati, kepala pembelajaran jenjang Pasca Amtsilati, pengurus bidang pembelajaran, serta perwakilan guru bersama- sama melaksanakan pembatasan kurikulum secara komprehensif. Komponen yang tercantum di dalam dokumen pembatasan kurikulum merupakan (1) Jenjang kelas, (2) Mata pelajaran, (3) Kompetensi kurikulum pondok, serta (4) Hasil pembatasan kurikulum. Hasil pembatasan kurikulum dijadikan rujukan buat meningkatkan silabus.

Pembatasan kurikulum ialah salah satu bagian dari perencanaan kurikulum di Pondok Pesantren Darul Falah “Amtsilati” Jepara yang lumayan unik. Pembatasan kurikulum tersebut mempermudah santri dalam mengukur ketercapaian kompetensi yang sudah dicapai. Sehingga pertumbuhan Pengajaran santri bisa terkendali dengan baik.

\section{Perumusan Silabus}

Silabus ialah dokumen perencanaan kurikulum Pondok Pesantren Darul Falah “Amtsilati” Jepara yang dibesarkan dari pembatasan kurikulum. Pengembangan silabus bertujuan buat menguraikan cakupan serta urutan kompetensi Pengajaran dari kelas sangat dasar hingga dengan kelas sangat atas; serta buat membiasakan kompetensi Pengajaran dengan tingkatan kelas. Proses pengembangan silabus didasarkan pada sistem yang dianut oleh pondok pesantren ialah sistem berbasis kompetisi serta kompetensi.

Pengembangan silabus di Pondok Pesantren Darul Falah “Amtsilati” Jepara dicoba secara kolaboratif, ialah seluruh anggota regu yang terdiri dari kepala pembelajaran jenjang Amtsilati, kepala pembelajaran jenjang Pasca Amtsilati, pengurus koordinator bidang pembelajaran, serta perwakilan guru bersama- sama melaksanakan pembatasan kurikulum, serta secara komprehensif, ialah mencakup totalitas tingakatan kelas dari kelas sangat dasar hingga kelas sangat atas. Komponen yang terdapat di dalam dokumen pengembangan silabus terdiri dari jenjang kelas, mata pelajaran, kompetensi Pengajaran, serta alokasi waktu. Pengembangan silabus dicoba secara mandiri oleh yang tergabung dalam pengurus bidang pembelajaran. 
Tetapi secara prinsip serupa dengan konsep silabus yang di informasikan oleh Majid kalau silabus merupakan rancangan Pengajaran yang berisi rencana bahan ajar mata pelajaran tertentu pada jenjang serta kelas tertentu. Selaku hasil dari pilih, pengelompokan, pengurutan, serta penyajian modul kurikulum yang dipertimbangkan bersumber pada karakteristik serta kebutuhan wilayah setempat. Silabus ialah seperangkat rencana dan pengaturan penerapan Pengajaran serta evaluasi yang disusun secara sistematis muat komponen- komponen yang silih barkaitan buat menggapai kemampuan kompetensi bawah.

Uraian di atas, bisa dikatakan kalau silabus yang ialah dokumen perencanaan Pengajaran di Pondok Pesantren Darul Falah “Amtsilati” Jepara wujudnya agak sedikit berbeda.

Bersumber pada ulasan menimpa perencanaan kurikulum di atas, Pondok Pesantren Darul Falah “Amtsilati” Jepara sudah menetapkan arah serta perencanaan Pengajaran selaku turunan dari visi, misi, serta tujuan pondok pesantren. Perencanaan kurikulum menganut sistem berbasis kompetisi serta kompetensi, sehingga kurikulum Pondok Pesantren Darul Falah "Amtsilati” Jepara diucap "Kurikulum Berbasis Kompetisi serta Kompetensi”. Dari kebijakan tersebut diresmikan perencanaan kurikulum yang terdiri dari pembatasan kurikulum serta formulasi silabus.

Bila memandang tujuan kurikulum bagi UU No 20 Tahun 2003 tentang Sistem Pembelajaran Nasional Bab 1 Pasal 1 Ayat 19 yang menarangkan kurikulum merupakan seperangkat rencana serta pengaturan menimpa tujuan, isi, serta bahan pelajaran dan metode yang digunakan selaku pedoman penyelenggaraan aktivitas Pengajaran buat menggapai tujuan pembelajaran tertentu. Dengan demikian, aplikasi perencanaan kurikulum di Pondok Pesantren Darul Falah "Amtsilati” Jepara melakukan tujuan kurikulum tersebut

Secara simpel, perencanaan kurikulum bersumber pada temuan- temuan riset di Pondok Pesantren Darul Falah “Amtsilati” Jepara, bisa ditafsirkan selaku berikut:

\section{Gambar 1. Perencanaan Kurikulum Pondok Pesantren Darul Falah} “Amtsilati" Jepara

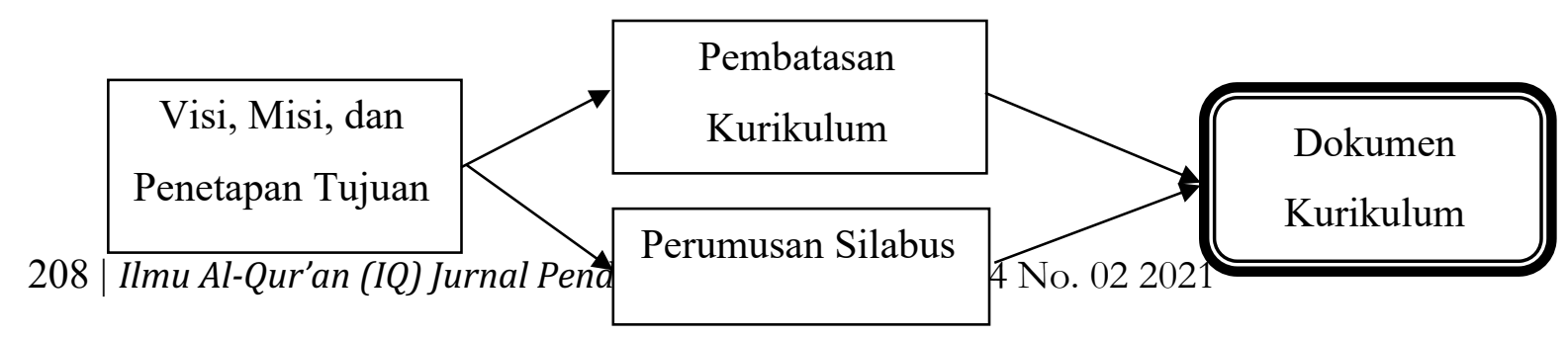




\section{Sumber: Hasil Pengolahan Mandiri Data Penelitian}

\section{B. Pengorganisasian Kurikulum}

Supaya implementasi kurikulum Pondok Pesantren Darul Falah "Amtsilati" Jepara berjalan efisien, hingga diresmikan serangkaian langkah- langkah pengorganisasian yang terdiri dari pimpinan pondok menetapkan kebijakan kurikulum, pengurus bidang pembelajaran menetapkan silabus, kepala pembelajaran Amtsilati serta Pasca Amtsilati dan pengurus bidang pembelajaran menetapkan struktur kurikulum serta agenda pelajaran, penjaga mengesahkan struktur kurikulum serta agenda pelajaran, penjaga menghasilkan SK penugasan serta pembagian tugas guru.

Struktur kurikulum Pondok Pesantren Darul Falah “Amtsilati” Jepara disesuaikan dengan jenjang Pembelajaran yang terdapat, ialah struktur kurikulum jenjang Pembelajaran Amtsilati serta struktur kurikulum jenjang pembelajaran Pasca Amtsilati. Pembagian kelas pada jenjang pembelajaran Amtsilati terdiri dari 6 kelas bersumber pada pembagian kitab Amtsilati yang jadi pegangan utama. Sedangkan buat jenjang pembelajaran Pasca Amtsilati terdiri dari 7 kelas bersumber pada pembagian bidang keilmuan Fiqih mulai dari kelas thoharoh hingga kelas tafsir.

Pembagian tugas guru dicoba dengan metode menganalisa informasi santri serta jumlah kelas, setelah itu tiap- tiap kepala jenjang pembelajaran menetapkan guru (jenjang Amtsilati menetapkan guru kelas, sebaliknya jenjang Pasca Amtsilati menetapkan guru kelas serta guru mata pelajaran), mengacu pada kualifikasi akademis serta pengalaman tiap- tiap guru pada tingkatan kelas ataupun mata pelajaran yang diajarkan, setelah itu sehabis itu penjaga menghasilkan pesan tugas mengajar untuk guru.

Bagi komentar Hasibuan yang menerangkan kalau pengorganisasian kurikulum merupakan sesuatu proses penentuan, pengelompokan, serta pengaturan beragam kegiatan yang dibutuhkan buat menggapai tujuan, menempatkan orang- orang pada tiap kegiatan, sediakan alat- alat yang dibutuhkan, menetapkan wewenang yang secara relatif didelegasikan kepada tiap orang yang melaksanakan aktifitas- aktifitas tersebut.

Hingga, aplikasi pengorganisasian kurikulum di Pesantren Darul Falah "Amtsilati" jepara melakukan perihal tersebut. ${ }^{13}$

${ }^{13}$ Malayu S.P Hasibuan, Manajemen, Dasar, dan Masalah, (Jakarta: Bumi Aksara,2016), 40 
Amtu mengatakan kalau guna pengorganisasian dimaksudkan buat memadukan segala sumber- sumber yang terdapat dalam organisasi, baik sumber energi manusia ataupun sumber energi yang lain ke arah tercapainya tujuan pembelajaran.

Pengorganisasian kurikulum di Pesantren Darul Falah “Amtsilati” jepara seluruh elemen dilibatkan baik elemen sumber energi manusia ataupun elemen sumber energi yang lain. Sebab hakikatnya dalam pengorganisasian merupakan memadukan segala sumber energi yang terdapat buat menggapai tujuan yang diresmikan.

Jadi, secara universal pengorganisasian kurikulum Pondok Pesantren Darul Falah “Amtsilati” Jepara terdiri dari 2 tahapan. Awal, penataan struktur kurikulum. Kedua, pembagian tugas guru/ delegasi wewenang.

\section{Struktur Kurikulum}

Struktur kurikulum Pondok Pesantren Darul Falah “Amtsilati” Jepara terdiri dari 2 tipe struktur kurikulum bersumber pada jenjang pembelajaran yang terdapat di Pondok Pesantren Darul Falah “Amtsilati” Jepara. Struktur kurikulum tersebut terdiri dari struktur kurikulum jenjang pembelajaran Amtsilati serta struktur kurikulum jenjang Pasca Amtsilati.

Struktur kurikulum pada jenjang pembelajaran pasca Amtsilati terdiri dari lintas kitab yang ialah gabungan kitab karangan penjaga pondok pesantren serta kitabkitab kuning yang universal digunakan di pesantren salaf semacam kitab Fathul Wahab, Fathul $\mathrm{Mu}$ ' in, Fathul Qorib serta seterusnya. Pembagian kelas pada jenjang Pembelajaran Pasca Amtsilati didasarkan pada keilmuan bidang ilmu Fiqih yang terdiri dari 7 kelas. Kelas 1 belajar kitab- kitab Fiqih bab Thoharoh, Kelas 2 belajar kitabkitab Fiqih bab Ubudiyah, Kelas 3 belajar kitab- kitab Fiqih bab Muamalah, Kelas 4 belajar kitab- kitab Fiqih bab Munakahat, Kelas 5 belajar kitab- kitab Fiqih bab Jinayat, Kelas 6 jadi guru tugas yang dikirim ke luar pondok pesantren sepanjang 6 bulan, serta Kelas 7 belajar kitab- kitab ilmu Tafsir.

Sebaliknya Struktur kurikulum pada jenjang Pembelajaran Amtsilati didasarkan pada kitab Amtsilati selaku mata pelajaran utama dengan pembagian kelas pula menjajaki pembagian pada kitab Amtsilati. Kelas 1 belajar Kitab Amtsilati jilid 1, Kelas 2 belajar Kitab Amtsilati jilid 2, Kelas 3 belajar Kitab Amtsilati jilid 3, Kelas 4 belajar Kitab Amtsilati jilid 4, Kelas 5 belajar Kitab Amtsilati jilid 5, serta Kelas 6 ataupun kelas praktek belajar Kitab praktek Amtsilati yang terdiri dari kitab Tatimmah, Shorfiyah, Qoidati, serta Khulasoh. 
Pada jenjang Pembelajaran Amtsilati, satu kelas fokus belajar satu mata pelajaran (kitab) hingga tuntas dengan penyelesaian riset bergantung keahlian serta intensitas santri. Sebaliknya pada jenjang Pasca Amtsilati, dalam satu kelas belajar sebagian mata pelajaran (kitab) cocok dengan tingkatan kelasnya tiap- tiap. Waktu penyelesaian riset di tiap- tiap kelas bergantung intensitas tiap- tiap santri. Santri yang giat serta aktif kilat naik kelas serta lulus, sebaliknya santri yang bermalas- malasan tertinggal.

Amtu pula menarangkan tujuan dari pengorganisasian (organizing) merupakan membagi aktivitas besar jadi kegiatan- kegiatan yang lebih kecil. Pembagian struktur kurikulum pada jenjang Pembelajaran Amtsilati serta jenjang Pasca Amtsilati dimaksudkan buat memudahkan proses penerapan kurikulum dalam wujud aktivitas belajar mengajar.

Dengan demikian, kurikulum yang berbasis kompetisi serta kompetensi, diharapkan sanggup mendesak serta memotivasi para santri buat belajar lebih aktif serta sungguh- sungguh, tidak menyia- nyiakan waktu belajar. Penetapan struktur kurikulum di Pondok Pesantren Darul Falah "Amtsilati" Jepara merupakan bersumber pada tingkatan keahlian santri pada tiap- tiap kelas.

\section{Pembagian Tugas Guru/Delegasi Wewenang}

Guru di Pondok Pesantren Darul Falah “Amtsilati” Jepara sebagian besar merupakan alumni pondok sendiri sebab memanglah Pondok Pesantren Darul Falah “Amtsilati” Jepara memiliki ciri tertentu dalam Pengajarannya, sehingga lebih gampang membiasakan diri dalam pengajarannya. Sebagian guru berasal dari luar pondok pesantren. Pembagian tugas guru di Pondok Pesantren Darul Falah “Amtsilati” Jepara bertujuan buat penuhi standar penerapan kurikulum pondok yang menganut sistem berbasis kompetisi serta kompetensi. Pertimbangan pembagian tugas guru di Pondok Pesantren Darul Falah "Amtsilati” Jepara bersumber pada kualifikasi akademis, pengalaman, serta hasil evaluasi guru.

Prosedur pembagian tugas guru di Pondok Pesantren Darul Falah“ Amtsilati” Jepara merupakan sabagai berikut: pimpinan pondok menganalisa penerapan kurikulum tahun ajaran tadinya; menganalisa informasi serta kebutuhan santri; menganalisa tenaga pengajar bersumber pada kualifikasi serta hasil evaluasi guru; menetapkan guru kelas buat jenjang pembelajaran Amtsilati serta menetapkan guru kelas dan guru bidang riset buat pembelajaran Pasca Amtsilati; setelah itu penjaga pondok pesantren menghasilkan pesan pembagian tugas guru. 
Bersumber pada ulasan menimpa pengorganisasian kurikulum di atas, pengorganisasian kurikulum di Pondok Pesantren Darul Falah “Amtsilati” Jepara diawali dari menetapkan struktur kurikulum serta setelah itu melaksanakan pembagian tugas guru. Lewat pengorganisasian kurikulum ini, guru serta pengelola pembelajaran memiliki cerminan yang tentang tujuan program Pembelajaran, bahan ajar, cakupan modul, penyajian modul, dan kedudukan guru serta santri dalam pengajaran.

Aplikasi pengorganisasian kurikulum di Pondok Pesantren Darul Falah“ Amtsilati” Jepara sejalan dengan rumusan yang di informasikan Rusman kalau organisasi kurikulum sangat terpaut dengan pengaturan bahan pelajaran yang terdapat dalam kurikulum, sebaliknya yang jadi sumber bahan pelajaran dalam kurikulum merupakan nilai budaya, nilai social, aspek siswa serta warga, dan ilmu pengetahuan serta teknologi. ${ }^{14}$

Secara simpel, pengorganisasian kurikulum bersumber pada temuan- temuan riset di Pondok Pesantren Darul Falah “Amtsilati” Jepara, bisa ditafsirkan selaku berikut:

Gambar 2. Pengorganisasian Kurikulum Pondok Pesantren Darul Falah "Amtsilati" Jepara

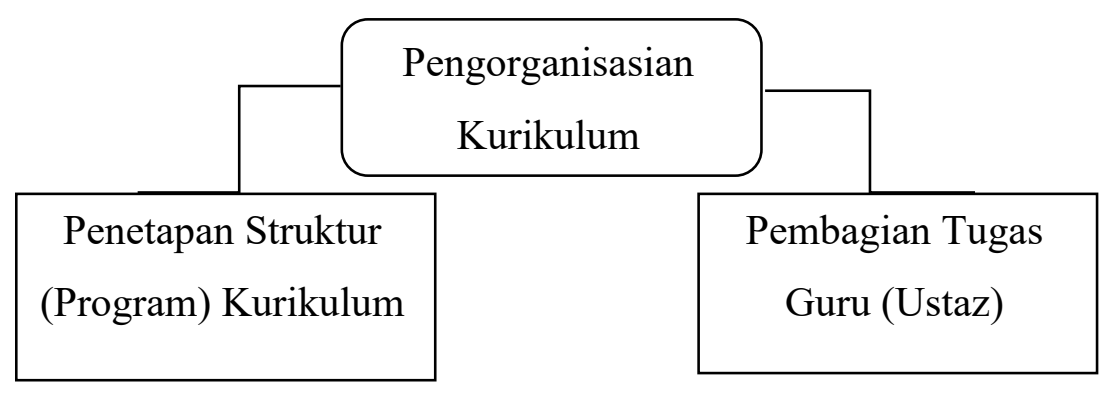

\section{Sumber: Hasil Pengolahan Mandiri Data Penelitian}

\section{Implementasi Kurikulum}

Supaya implementasi kurikulum cocok dengan visi serta misi pondok pesantren, hingga diresmikan prosedur serta langkah- langkah: sehabis dokumen kurikulum (silabus) disahkan oleh penjaga pondok pesantren, guru melakukan Pengajaran bersumber pada petunjuk yang terdapat di silabus. Pada jenjang Pembelajaran Amtsilati, guru mengajar dengan metode: membacakan modul berikut contohnya; santri mengulangi baca guru

\footnotetext{
${ }^{14}$ Rusman, Manajemen Kurikulum, (Jakarta: PT RajaGrafindo Persada, 2011), 60.

212 | Ilmu Al-Qur'an (IQ) Jurnal Pendidikan Islam | Volume 4 No. 022021
} 
diiringi nadzoman ataupun dasarnya; guru menerangkan isi modul secara jelas; santri bertanya apabila terdapat yang tidak dimengerti; guru menanggapi persoalan santri; sehabis itu santri menghafal Qoidah serta dasarnya bersumber pada modul yang sudah dipelajari; evaluasi dicoba lewat uji tulis serta lisan( hafalan).

Implementtasi kurikulum di Pondok Pesantren Darul Falah “Amtsilati” Jepara dilaksanakan dalam wujud aktivitas Pengajaran. Pondok Pesantren Darul Falah “Amtsilati” Jepara melaksanakan 3 model aktivitas Pengajaran, ialah Pengajaran klasikal (intrakurikuler), Pengajaran non klasikal (co- kurikuler), serta ekstrakurikuler.

Sebaliknya pada jenjang pembelajaran Pasca Amtsilati, guru mengajar lewat: membacakan kitab cocok modul yang dipelajari; santri memaknai kitab yang dibaca oleh guru; guru menerangkan isi kitab yang dibaca; santri bertanya apabila terdapat yang tidak dimengerti; serta guru menanggapi persoalan santri; evaluasi dicoba lewat uji lisan membaca kitab kuning berikut pemahamannya.

Penerapan Pengajaran di Pondok Pesantren Darul Falah "Amtsilati” Jepara menganut sistem berbasis kompetisi serta kompetensi yang bisa memicu motivasi belajar santri lewat persaingan secara sehat di antara santri, sehingga bisa meminimalisir santri buat bermalas- malasan sebab tertinggal oleh santri yang lain.

Dalam mengimplementasikan kurikulum pada proses Pengajaran, Pondok Pesantren Darul Falah“ Amtsilati” Jepara melaksanakan 3 model aktivitas Pengajaran, ialah Pengajaran klasikal( intrakurikuler), Pengajaran non klasikal( co- kurikuler), serta ekstrakurikuler.

Pengajaran klasikal ataupun intrakurikuler digunakan pada jenjang pembelajaran utama yang terdapat di Pondok Pesantren Darul Falah “Amtsilati” Jepara, ialah jenjang Pembelajaran Amtsilati serta jenjang Pembelajaran Pasca Amtsilati. Kedua jenjang pembelajaran tersebut harus diiringi oleh tiap santri mukim sampai lulus. Sedangkan untuk santri non mukim ataupun santri kilatan, mereka cuma harus menjajaki program yang diambil saja, semacam program Amtsilati satu pekan serta program Amtsilati satu bulan.

Jenjang pembelajaran Amtsilati serta Pasca Amtsilati dilaksanakan tiap hari dari jam 08. 00 hingga dengan jam 11. 00, kecuali hari Selasa pagi (aktivitas ekstrakurikuler) serta hari Jumat( libur mingguan). Siang hari hingga sore hari dipakai buat sekolah resmi. Untuk santri yang tidak menjajaki sekolah resmi, pondok pesantren memfasilitasi dengan program takhassus ataupun program spesial Pengajaran kitab kuning yang dilaksanakan pada jam sekolah resmi. 
Sebaliknya Pengajaran non klasikal diberlakukan dalam aktivitas pengajian kitab kuning yang diselenggarakan secara universal ataupun diucap bandongan serta diiringi oleh seluruh santri tanpa membedakan kelas serta jenjang pembelajaran. Tujuan aktivitas ini salah satunya merupakan buat praktek memaknai serta menganalisis kitab kuning. Tidak hanya itu pula diberlakukan pada aktivitas mengaji al- Qur' an.

Impelementasi kurikulum di Pondok Pesantren Darul Falah“ Amtsilati” Jepara sejalan dengan yang dikemukakan oleh Hamalik, kalau implementasi kurikulum merupakan pelaksanaan ataupun penerapan program kurikulum yang sudah dibesarkan dalam sesi tadinya, setelah itu diujicobakan dengan penerapan serta pengelolaan, sembari tetap dicoba penyesuaian terhadap suasana lapangan serta ciri partisipan didik, baik pertumbuhan intelektual, emosional, dan fisiknya. ${ }^{15}$

Dengan demikian, secara universal implementasi kurikulum di Pondok Pesantren Darul Falah "Amtsilati” Jepara terdiri dari 2 kompenen. Awal, pemberian pengalaman belajar (pengajaran). Kedua, evaluasi serta laporan hasil belajar.

\section{Pengalaman Pengajaran}

Pondok Pesantren Darul Falah "Amtsilati" Jepara dalam melaksanakan Pengajaran berpedoman pada sistem berbasis kompetisi dan kompetensi. Pelaksanaan Pengajaran didasarkan pada silabus yang telah disusun pada proses perencanaan kurikulum.

Kegiatan Pengajaran jenjang Pendidikan Amtsilati dilakukan dengan cara: guru membacakan materi berikut contohnya; santri mengulangi baca guru disertai nadzoman atau dasarnya; guru menerangkan isi materi secara jelas; santri bertanya apabila ada yang tidak dipahami; guru menjawab pertanyaan santri; santri menghafal Qoidah dan dasarnya berdasarkan materi yang telah dipelajari; dan penilaian dilakukan melalui tes tulis dan lisan (hafalan). Sedangkan pada jenjang pendidikan Pasca Amtsilati, guru mengajar dengan cara: membacakan kitab sesuai materi yang dipelajari; santri memaknai kitab yang dibaca oleh guru; guru menerangkan isi kitab yang dibaca; santri bertanya apabila ada yang tidak dipahami; guru menjawab pertanyaan santri; dan penilaian dilakukan melalui tes lisan dengan membaca kitab kuning berikut pemahamannya.

${ }^{15}$ Oemar Hamalik, Dasar-Dasar Pengembangan Kurikulum, (Bandung: PT Remaja Rosdakarya, 2008), 
Pendekatan yang digunakan dalam kegiatan Pengajaran di Pondok Pesantren Darul Falah “Amtsilati” Jepara adalah pendekatan berbasis kompetisi dan kompetensi, yaitu santri dalam proses pengalaman Pengajaran yang dilalui selain dituntut memiliki kompetensi keilmuan nahwu sharaf dan kemampuan membaca kitab kuning, juga dituntut berpacu dengan waktu untuk menyelesaikan seluruh Pengajaran dalam waktu yang sesingkat-singkatnya. Santri yang sudah merasa mampu pada kelas tertentu boleh melakukan tes kenaikan kelas. Pengalaman Pengajaran juga yang didapat oleh santri adalah Pondok Pesantren Darul Falah “Amtsilati” Jepara mempunyai metode Amsilati, metode cepat dan praktis membaca kitab kuning yang menjadi ciri khas pondok pesantren.

\section{Penilaian dan Laporan Hasil Belajar}

Tujuan dari evaluasi di Pondok Pesantren Darul Falah “Amtsilati” Jepara merupakan buat mengukur keahlian kompetensi santri. Prinsip bawah dalam evaluasi di Pondok Pesantren Darul Falah “Amtsilati” Jepara ialah santri yang telah merasa sanggup buat melaksanakan uji ataupun tes, dipersilahkan buat mendaftarkan diri ke pengurus penyelenggara tes. Jenjang Pembelajaran Amtsilati ke Tubuh Spesial (Bansus) Amtsilati, jenjang Pembelajaran Pasca Amtsilati ke pengurus Akademik.

Bersumber pada ulasan di atas, implementasi kurkulum di Pondok Pesantren Darul Falah“ Amtsilati” Jepara terdiri dari 2 bagian ialah, pengalaman Pengajaran serta evaluasi serta laporan hasil belajar. Pendekatan Pengajaran berbasis kompetisi serta kompetensi. Santri yang telah merasa sanggup, boleh mendaftarkan diri buat melaksanakan tes ataupun uji. Sumber belajar berasal dari kitab- kitab karangan penjaga pondok sendiri serta kitab- kitab karya ulama salaf yang lain yang universal digunakan di pesantren salaf. Aktivitas Pengajaran di Pondok Pesantren Darul Falah “Amtsilati” Jepara secara universal dibagi jadi 3 kelompok, yaiitu aktivitas Pengajaran intrakurikuler, co-kurikuler, serta ekstrakurikuler.

Evaluasi Pengajaran di Pondok Pesantren Darul Falah "Amtsilati” Jepara dicoba dengan uji tulis serta uji lisan. Uji tulis dicoba dengan mengerjakan soal tes, uji lisan dicoba dengan mambaca kitab kuning serta setoran hafalan. Hasil evaluasi tertuang dalam wujud SKHU (Pesan Keterang Hasil Tes).

Rusman mengatakan terpaut implementasi kurikulum di tingkatan kelas bahhwa sesuatu pembelajarn dalam kelas ialah tempat buat melakukan serta menguji kurikulum. Perihal iini nampak kalau dalam penerapannya di lapangan seluruh aktivitas Pengajaran seluruh konsep, prinsip, nilai, pengetahuan, tata cara, perlengkapan, serta 
keahlian guru diuji dalam wujud perbuatan yang mewujudkan wujud kurikulum yang nyata. ${ }^{16}$

Secara simpel, implementasi kurikulum berdasarkan temuan-temuan penelitian di Pondok Pesantren Darul Falah "Amtsilati” Jepara, dapat digambarkan sebagai berikut:

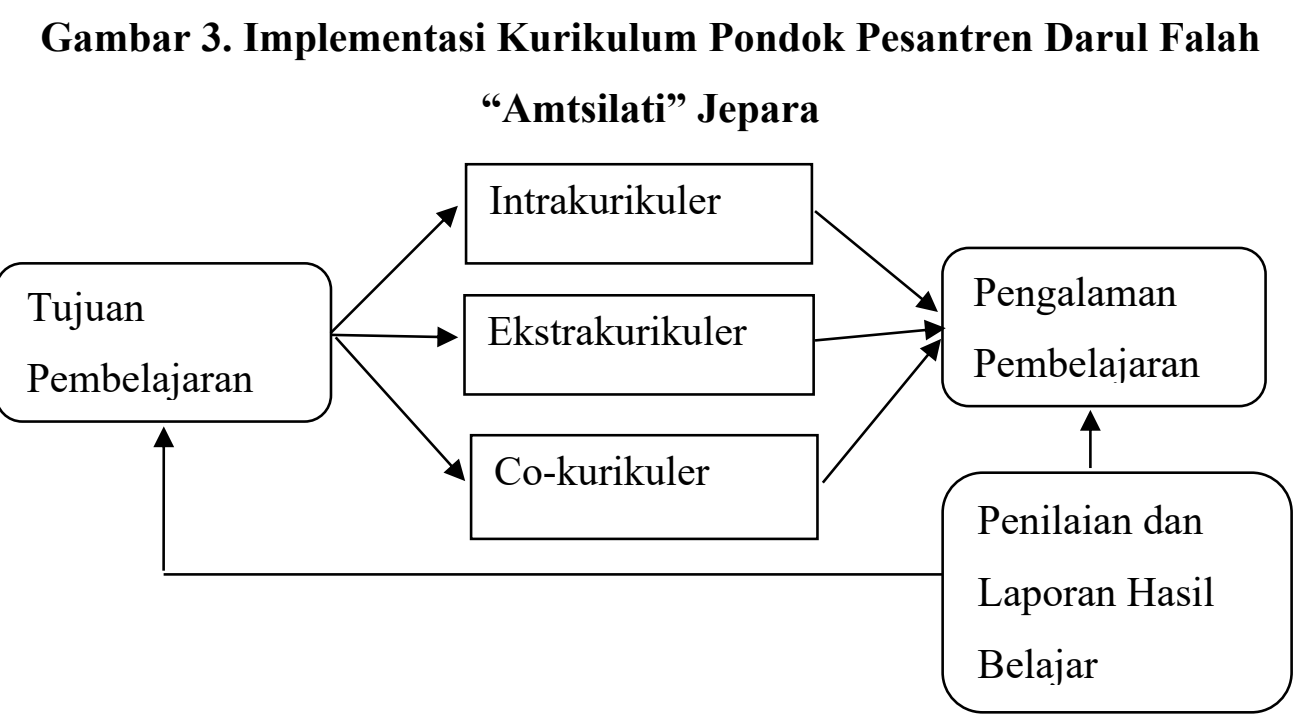

\section{Sumber: Hasil Pengolahan Mandiri Data Penelitian}

\section{Evaluasi Kurikulum}

Penilaian ataupun peninjauan kurikulum ialah perihal yang sangat berarti di Pondok Pesantren Darul Falah “Amtsilati” Jepara supaya kurikulum yang diterapkan cocok dengan kebutuhan santri. Bersumber pada hasil wawancara, observasi, serta riset dokumentasi, penemuan riset menampilkan kalau penilaian kurikulum di Pondok Pesantren Darul Falah" Amtsilati” Jepara dicoba secara bertahap serta berkesinambungan lewat mekanisme musyawarah( rapat) mulai dari penilaian bulanan, triwulan, serta per 6 bulan. Penilaian dicoba buat mengukur apakah kurikulum yang dijalankan telah cocok dengan perencanaan ataupun masih terdapat kekurangan ataupun apalagi butuh terdapat penyesuaian.

Berdialog penilaian kurikulum, tidak terlepas dari penilaian pembelajaran serta penilaian Pengajaran dalam lingkup yang lebih kecil. Ketiganya mempunyai mempunyai ciri yang tidak terpisahkan. Implementasi kurikulum ialah siklus tahunan, hingga butuh dicoba peninjauan ataupun penilaian kurikulum.

\footnotetext{
${ }^{16}$ Rusman, Manajemen Kurikulum, (Jakarta: PT RajaGrafindo Persada, 2011), 75

216 | Ilmu Al-Qur'an (IQ) Jurnal Pendidikan Islam | Volume 4 No. 022021
} 
Jadi, secara universal penilaian kurikulum yang diterapkan di Pondok Pesantren Darul Falah “Amtsilati” Jepara terdiri dari 2 tipe. Awal, penilaian mata pelajaran. Kedua, penilaian waktu penyelesaian Pengajaran.

\section{Evaluasi Mata Pelajaran}

Penilaian mata pelajaran di Pondok Pesantren Darul Falah “Amtsilati” Jepara bertujuan buat mengevaluasi ketercapaian kompetensi serta tujuan Pengajaran, menganalisa kesesuaian kompetensi dengan tingkatan kelas, serta menganalisa kedalaman modul. Di Pondok Pesantren Darul Falah “Amtsilati” Jepara, penilaian mata pelajaran dicoba pada bulan Syawal serta bulan Maulid. Prinsip bawah penilaian mata pelajaran ialah, keragaman style belajar santri, cakupan kompetensi, serta kesesuaian modul dengan tingkatan kelas santri.

Prosedur penilaian mata pelajaran yang dicoba di Pondok Pesantren Darul Falah" Amtsilati” Jepara merupakan pengurus bidang Pembelajaran serta guru mata pelajaran duduk bersama mendiskusikan hal- hal yang butuh ditingkatkan serta dibesarkan, pengurus bidang Pembelajaran serta guru mata pelajaran melaksanakan perbaikan pada dokumen silabus kurikulum, kepala jenjang Pembelajaran( Amtsilati serta Pasca Amtsilati) serta pimpinan pondok melaksanakan verifikasi, serta penjaga pondok pesantren mengesahkan dokumen silabus kurikulum yang baru.

\section{Evaluasi Waktu Penyelesaian Pengajaran}

Prosedur penilaian waktu penyelesaian Pengajaran santri di Pondok Pesantren Darul Falah “Amtsilati” Jepara ialah guru ataupun ustaz pembimbing memberi tahu pertumbuhan belajar santri; segala partisipan rapat mengenali santri- santri yang hadapi hambatan dalam Pengajarannya sehingga membuat lama; partisipan rapat silih berikan masukan; mencatat hasil selaku bahan tindak lanjut.

Bersumber pada ulasan tentang penilaian kurikulum di atas, penerapan penilaian kurikulum Pondok Pesantren Darul Falah “Amtsilati” Jepara memakai pendekatan inklusif ialah pendekatan yang mengaitkan bermacam pihak dengan memandang berbagai aspek pengembangan kurikulum. Pihak-pihak yang ikut serta dalam penerapan penilaian kurikulum merupakan guru, pengurus bidang Pembelajaran, kepala jenjang pembelajaran (Amtsilati serta Pasca Amtsilati), serta pimpinan pondok. Penilaian kurikulum di Pondok Pesantren Darul Falah “Amtsilati” Jepara terdiri dari penilaian mata pelajaran serta penilaian waktu penyelesaian Pengajaran.

Aplikasi penilaian yang dicoba Pondok Pesantren Darul Falah“ Amtsilati” Jepara sejalan dengan yang diungkapkan Gronlud dalam Rusman kalau penilaian 
kurikulum ialah sesuatu proses sistematis dari pengumpulan analisis serta interpretasi informasi/ data buat memastikan sepanjang mana siswa sudah menggapai tujuan pengajaran. ${ }^{17}$

Jelasnya penilaian kurikulum bertujuan buat mengecek kinerja kurikulum secara totalitas ditinjau dari bermacam kriteria.

Secara simpel, Penilaian kurikulum bersumber pada temuan- temuan riset di Pondok Pesantren Darul Falah “Amtsilati” Jepara, bisa ditafsirkan selaku berikut:

\section{Gambar 4. Evaluasi Kurikulum Pondok Pesantren Darul Falah}

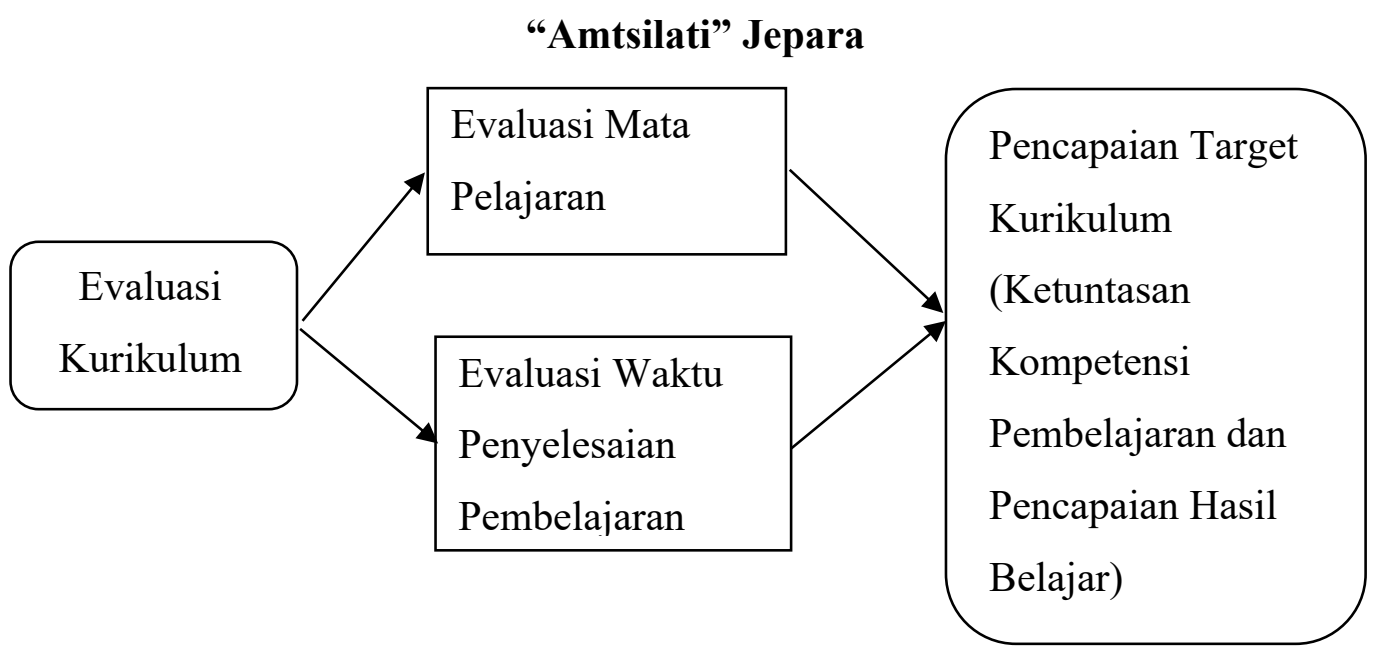

Sumber: Hasil Pengolahan Mandiri Data Penelitian

\section{Kesimpulan}

Berdasarkan hasil dan pembahasan penelitian yang telah dipaparkan, maka dapat disimpulkan manajemen kurikulum Pondok Pesantren Darul Falah "Amtsilati” Jepara menggunakan kurikulum yang berbasis kompetensi dan kompetisi. Dengan memperhatikan aspek perencanaan kurikulum atau planning, perorganisasian kurikulum atau organazing, implementasi kurikulum atau pelaksanaan dan evaluasi kurikulum atau evaluation. Dengan kata lain, manajemen kurikulum di Pondok Pesantren Darul Falah “Amtsilati” Jepara ini berbeda dari pondok pesantren lainnya dan memiliki khas.

\footnotetext{
${ }^{17}$ Rusman, Manajemen Kurikulum, (Jakarta: PT RajaGrafindo Persada, 2011), 93.

218 | Ilmu Al-Qur'an (IQ) Jurnal Pendidikan Islam | Volume 4 No. 022021
} 


\section{Daftar Pustaka}

Amtu, Onisimus. Manajemen Pendidikan di Era Otonomi Daerah: Konsep, Strategi, dan Implementasi. Bandung: Alfabeta, 2011.

Arikunto, Suharsimi. Prosedur Penelitian. Jakarta: Rieneka Cipta, 2000.

Hamalik, Oemar. Dasar-Dasar Pengembangan Kurikulum. Bandung: PT Remaja Rosdakarya, 2008.

. Manajemen Pengembangan Kurikulum. Bandung: SPs UPI dan PT Remaja Rosdakarya. 2008.

Hasibuan, Malayu S.P. Manajemen, Dasar, dan Masalah, Jakarta: Bumi Aksara, 2016.

Majalah Kisah Islami (alKisah) No.08/7-20 April 2008.

Majid, Abdul. Perencanaan Pengajaran: Mengembangkan Standar Kompetensi Guru. Bandung: Remaja Rosdakarya, 2011.

Maulana, Fikri. "Pendidikan Kewirausahaan Dalam Islam." IQ (Ilmu Al-Qur'an): Jurnal Pendidikan Islam 2, no. 01 (January 1, 2019): 30-44. https://doi.org/10.37542/IQ.V2I01.23.

Moleong, Lexy J. Metodologi Penelitian Kualitatif. Bandung: Remaja Rosdakarya. 2010.

Muin, Abd. M dkk. Pesantren dan Pengembangan Ekonomi Umat, Jakarta: CV. Prasasti, 2007.

Multisitus, Studi, Beberapa Pesantren, Salaf Di, Jawa Tengah, and Rustam Ibrahim. “EKSISTENSI PESANTREN SALAF DI TENGAH ARUS PENDIDIKAN MODERN

The Existence of Salaf Islamic Boarding School amid the Flow of Modern Education (A Multi-Site Study at Pesantren Salafy in Central Java)," no. 1 (2014): 253-63.

Rusman. Manajemen Kurikulum. Jakarta: PT RajaGrafindo Persada. 2011.

Sugiyono. Metode Penelitian Kuantitatif, Kualitatif dan R \& D. Bandung: Alfabeta, 2013.

Undang-Undang RI Nomor 20 Tahun 2003 tentang Sistem Pendidikan Nasional Bab 1 Pasal 1 Ayat 19.

Ibrahim, Rustam. Eksistensi Pesantren Salaf di Tengah Arus Pendidikan Modern (Studi Multisitus Pada Beberapa Pesantren Salaf di Jawa Tengah). Dalam Jurnal Jurnal “Analisa” Volume 21 Nomor 02 Desember 2014, 253-263. http://blasemarang.kemenag.go.id/journal/index.php/analisa/article/view/19 (Diakses 21 November 2020).

Weldon F. Zenger and Sharon K. Zenger, Curriculum Planning: Outcames-Based Accountability. Direction Journal Vol.23 No.2, 1994. 
Mufassirul Alam dan Fikri Maulana

http://www.directionjournal.org/23/2/curriculum-planning-outcomes-based.html.

(Diakses 20 Januari 2021).

http://pendis.kemenag.go.id/file/dokumen/bukusaku1102.pdf. (Diakses 25 Desember 2017). www.kemenag.go.id. (Diakses 12 September 2021).

www.pendis.kemenag.go.id. (Diakses 12 September 2021).

www.republika.co.id. (Diakses 12 September 2021). 